\title{
Teacher Stress and Coping Strategies-The Struggle to Stay in Control
}

\author{
Einar M. Skaalvik ${ }^{1,2}$, Sidsel Skaalvik ${ }^{2}$ \\ ${ }^{1}$ NTNU Social Research, Trondheim, Norway \\ ${ }^{2}$ Norwegian University of Science and Technology, Trondheim, Norway \\ Email: einar.skaalvik@ntnu.no,sidsel.skaalvik@ntnu.no
}

How to cite this paper: Skaalvik, E. M., \& Skaalvik, S. (2021). Teacher Stress and Coping Strategies-The Struggle to Stay in Control. Creative Education, 12, 1273-1295. https://doi.org/10.4236/ce.2021.126096

Received: May 14, 2021

Accepted: June 14, 2021

Published: June 17, 2021

Copyright () 2021 by author(s) and Scientific Research Publishing Inc. This work is licensed under the Creative Commons Attribution International License (CC BY 4.0).

http://creativecommons.org/licenses/by/4.0/ (c) (i) Open Access

\begin{abstract}
This qualitative interview study explored primary and middle school teachers' perceptions of job demands, how they responded to the demands, and which strategies they used to cope with the demands. The participating teachers reported multiple demands, resulting in high levels of stress and emotional exhaustion. Several of the demands could be traced back to structural and organizational conditions at the schools. The analyses also showed that the teachers used five main strategies to cope with the demands: hard working strategies, recovering strategies, reducing the workload strategies, job crafting strategies, and help seeking strategies.
\end{abstract}

\section{Keywords}

Teacher Stress, Job Demands, Coping Strategies

\section{Introduction}

Research during the last couple of decades has shown that, although rewarding, teaching is a stressful occupation and teacher stress is an international phenomenon (Chan, 2002; Johnson, Cooper, Cartwright, Donald, Taylor, \& Millet, 2005; Liu \& Onwuegbuzie, 2012; Montgomery \& Rupp, 2005; Skaalvik \& Skaalvik, 2017a, 2017b; Stoeber \& Rennert, 2008). Conditions in the school environment that are associated with stress are workload or time pressure, student diversity, discipline problems, low student motivation, value conflicts, lack of recognition, lack of shared decision making, lack of autonomy, conflicts with colleagues, parents, or the school administration, lack of administrative support, low pay and low status (e.g., Betoret, 2009; Fernet, Guay, Senécal, \& Austin, 2012; Friedman, 1995; Hakanen, Bakker, \& Schaufeli, 2006; Klassen \& Chiu, 2011; Kokkinos, 2007; Skaalvik \& Skaalvik, 2009, 2011, 2015). Such conditions 
are, in the research literature, termed stressors or job demands. In an interview study of 30 teachers, Skaalvik \& Skaalvik (2015) found three categories of consequences of teacher stress: 1) exhaustion and psychosomatic symptoms, 2) reduced accomplishment and loss of self-efficacy, and 3) negative affect and loss of self-esteem. Teacher stress is also associated with attrition (Borman \& Dowling, 2008) and, among working teachers, with the motivation to leave the teaching profession (Skaalvik \& Skaalvik, 2018).

Although much research is done examining stressors in the teaching profession, research exploring organizational antecedents of stressors and teachers' strategies to stay in control is generally lacking. This study focuses on teachers' perceptions of job demands and their strategies to coop with job demands in the school environment. One purpose was to explore how the teachers explained work-related stress in open-ended interviews. Another purpose was to explore what teachers are doing in order to stay in control or to cope with stressful working conditions.

\section{Theoretical Framework}

\subsection{The Job Demands-Resources Model (JD-R Model)}

The Job Demands-Resources model (JD-R model; Demerouti, Bakker, Nachreiner, \& Schaufeli, 2001) proposes that in all occupations one may distinguish between two categories of work characteristics: job demands and job resources. In this study we were occupied by perceived job demands. Job demands may be defined as physical, social, or organizational aspects of the job that require sustained physical or mental effort (Demerouti et al., 2001: p. 501). Examples of job demands offered by Bakker and Demerouti (2006) are: work overload, unfavorable physical environments, and emotionally demanding social interactions. Importantly, as noted by C. Skaalvik (2020), job demands are not necessarily negative and work-related challenges may even be stimulating. However, demands may turn into stressors when high and sustained efforts are required to meet the demands (Bakker \& Demerouti, 2006). The JD-R model builds on the assumption that sustained job demands may lead to a health impairment process, often described as a depletion of energy, emotional exhaustion, burnout, and health problems (Bakker \& Demerouti, 2006). Supporting these assumptions, Hakanen et al. (2006), in a study of Finish teachers, found that a latent job demand variable was associated with teacher burnout, and C. Skaalvik (2020), in a study of Norwegian school principals found that time pressure and demanding parents was associated with emotional exhaustion.

\subsection{Striving for Control}

The assumption that people are pursuing control over their life is underlying several motivational theories. For instance, White (1959) assumed that people are motivated to understand and master the environment in order to make it more predictable and controllable. White's idea was further developed by Harter 
(1982) and termed competence motivation. Harter proposed that motivation, in part, resulted from the belief that one could exert control over the environment. Self-determination theory (Deci \& Ryan, 2000) is also based on the assumption that people have a basic psychological need for autonomy and control. Schunk, Pintrich and Meece (2010) describe autonomy as the need to feel a sense of control, or to perceive an internal locus of causality. The pursuit of control is also evident in self-worth theory (Covington, 1992). According to Covington (1992) the need for self-worth may generate behaviors aimed at controlling how one's achievements are attributed by others. This may result in self-handicapping behaviors but also hiding how much effort one put into a task (S. Skaalvik, 1995).

That people are pursuing control is also a central idea in social cognitive theory. Bandura (1997) claims that "People have always striven to control events that affect their lives" (p. 1) and that "The striving for control over life circumstances permeates almost everything people do throughout the live course" (p. 1-2). In social cognitive theory the striving for control is not seen as an inborn drive-people seek control in order to make the environment predictable and for the benefit they gain by being in control (Bandura, 1997). Social cognitive theory not only claim that people strive for control, but that they, through the exercise of human agency, reflective thought, and self-regulation have the capacity to influence their environment and their life circumstances. In Bandura's words, "To be an agent is to influence intentionally one's functioning and life circumstances."

\subsubsection{Personal, Proxy, and Collective Control}

Social-cognitive theory distinguishes among three different forms of agency or control - personal, proxy, and collective (Bandura 1997, 2000). Personal control refers to agency exercised personally. The exercise of personal control requires that one has, or is able to acquire the sufficient knowledge and skill, but also that one believes that one is able to exercise control (self-efficacy). Bandura reminds us that if people believe that they are not able to change the circumstances or influence their situation, they will likely not attempt to do so. He claims that "Among the mechanisms of personal agency, none is more central or pervasive than people's beliefs about their capabilities to exercise control over events that affect their lives" (Bandura 2000: p. 1175).

An alternative to personal control is to seek proxy control. Seeking proxy control means that people try to get other people, who possess the necessary competence and influence, to act on their behalf to effect the desired changes (Bandura, 1997). If people lack the necessary knowledge or skills to exercise personal control, they may seek proxy control (Bandura, 1997). Also, people who doubt their personal capabilities to exercise personal control may, regardless of their actual capability seek proxy control. Furthermore, people may also seek proxy control for the sake of convenience. It may be easier or quicker to seek proxy control than to spend time acquiring the necessary knowledge and skills. However, people vary in how comfortable they are with being dependent on other people (Bandura, 1997). 
A third form of control, collective control (or collective agency) means that goals are pursued through collaboration. Bandura (2000) maintains that many of the outcomes people seek can only be obtained through shared effort and many situations can only be changed through collective agency.

To summarize, social cognitive theory proposes three forms of control: personal, proxy, and collective. People choose these forms of control for different reasons: judgments of personal capability, convenience, habitual behavior, access to resource persons, and what the situation or the goal requires. In the actual teaching situation teachers are traditionally alone with their students. During lessons, teachers in traditional schools therefore must exercise personal control. However, many schools in Norway are "open area schools" and in some of these schools, teachers are working in teams sharing the responsibility for a larger group of students. In such schools some degree of proxy or collective control may be exercised even during the teaching sessions. We also expect that teachers may seek some degree of proxy control between or after teaching sessions, for instance seeking advice from colleagues or the school leadership.

\subsubsection{Primary and Secondary Control}

Rothbaum, Weisz and Snyder (1982) discriminate between primary control and secondary control. In their conceptualization, primary control means that people change or try to change the existing realities-the situation, the social structures, the goals, the work tasks etc. In contrast, secondary control means that instead of changing the situation, people try to make the best out of the seemingly unchangeable situation and to reduce the negative consequences of the situation. Imagine a teacher with discipline problems in his or her class. In this case, primary control means that the teacher was able to reduce the discipline problems in one way or another, whereas secondary control means that the teacher somehow found a way to accept the situation and do the best out of it, but without reducing or being able to reduce the disruptive student behavior. Theoretically, both primary and secondary control may be exercised as personal, proxy, or collective control.

\subsubsection{Positive and Negative Control}

In a study of adults with severe reading problems, S. Skaalvik (1995) discriminates between positive and negative control. Thinking back on their schooldays, the informants reported that the reading problems made the school situation threatening, both because the acquisition of information in school was heavily based on student reading and because they feared being perceived as stupid by their classmates. The informants used two main strategies to control their school situation. S. Skaalvik (1995) termed these strategies positive and negative control. Positive control was aimed at changing the situation, either by improving their reading skills or by acquiring information by other means than reading the textbooks, for instance by asking classmates and parents to retell the content of the textbooks. By aiming to change the situation, positive control resembles what 
Rothbaum et al. (1982) termed primary control. Compensating for their lack of reading skills by seeking help from their classmates was also termed positive control because it helped improving their academic performances. This strategy required that they were open about the problems. The examples show that positive control might be exercised both as personal and proxy control.

By negative control, S. Skaalvik (1995) refers to trying to hide both the reading problems and the following problems with mastering the requirements in school. This strategy was termed negative control for two reasons. Firstly, it was not functional in solving the problems, which in this case would be improving either the students' reading skills or their general academic performances. Secondly, it resulted in additional problems like tension and anxiety-the informants reported a continuous anxiety that their deficiencies would be exposed. They were constantly occupied by avoiding answering questions in class and hiding their written work. Hence, in the informants' school situation negative control cannot be exercised as proxy control or collective control.

\subsubsection{Types of Control-A Comparison}

Whereas the distinction between personal, proxy, and collective control refers to who is participating and who is contacted in order to exercise control, the distinction between primary and secondary control, but also between positive and negative control, refers to the goal of the control-what the control aims at achieving. Primary control and positive control overlap each other in that the control aims at changing the situation, for instance to make the tasks less challenging or by improving one's skills. Secondary control and negative control also overlap in that the aim of the control is to make the situation livable even if one cannot change it.

\subsection{The Present Study}

The purpose of the study was, through open ended interviews with six teachers in elementary school and middle school, to explore teachers' perceptions of job demands (e.g., challenges in their work and obstacles in achieving their goals) as well as their strategies to cope with their work situation. More specifically, we attempted to shed light on the following research questions:

1) Which challenges and obstacles did the teachers describe?

2) How did they describe their emotional reactions to the obstacles?

3) Which strategies did they use in order to control their work situation?

\section{Method}

\subsection{Participants}

The participants in this study were six teachers working in elementary school and middle school in Norway. Both Norwegian elementary school (grade $1-7$ ) and middle school (grade 8 - 10) follow a national curriculum. Pupils attend their local school and permanent level grouping is not allowed. The teachers therefore encounter great variation in the students' abilities. 
The teachers were recruited in order to ensure variation in gender and age of the teachers, at which level they were teaching (elementary school and middle school) and classroom schools verses open area schools. We started the sampling process by choosing three primary schools and three middle schools. Two of the primary schools were open area schools and one was a classroom school whereas one of the middle schools was an open area school and two of the middle schools were classroom schools. At each of the schools we then invited one teacher to participate. This was done in order to ensure the variation. For instance, at one elementary school with separate classrooms we invited a female senior teacher and at one elementary open area school we invited a young male teacher.

For an overview of the participants, see Table 1. Three of the participants were females (Hanna, Jane, and Mary) whereas three were males (Jon, Richard, and Sam). Two of the teachers were defined as young (27 - 34 years), two as middle aged (35 - 50 years), and two as senior teachers (51 - 63 years). Three of the teachers were working in elementary schools and three in middle schools. Also, three of the teachers were working in classroom schools and three in open area schools. Open area schools were defined as schools were at least all students at the same grade level were thought in the same open area whereas classroom schools were defined as schools with separate classrooms for each class.

Table 1. Overview of the participants.

\begin{tabular}{|c|c|c|c|c|c|c|}
\hline & Hanna & Jane & Mary & Jon & Richard & Sam \\
\hline \multicolumn{7}{|l|}{ Age } \\
\hline Young & & & & & $\mathrm{X}$ & $\mathrm{X}$ \\
\hline Middle aged & $\mathrm{X}$ & $\mathrm{X}$ & & & & \\
\hline Senior & & & $\mathrm{X}$ & $\mathrm{X}$ & & \\
\hline \multicolumn{7}{|l|}{ Grade level } \\
\hline Elementary & $\mathrm{X}$ & & $\mathrm{X}$ & & & $\mathrm{X}$ \\
\hline Middle school & & $\mathrm{X}$ & & $\mathrm{X}$ & $\mathrm{X}$ & \\
\hline \multicolumn{7}{|l|}{ Architecture } \\
\hline Separate classrooms & & $\mathrm{X}$ & $\mathrm{X}$ & & $\mathrm{X}$ & \\
\hline Open landscape & $\mathrm{X}$ & & & $\mathrm{X}$ & & $\mathrm{X}$ \\
\hline \multicolumn{7}{|l|}{ Teaching assignments } \\
\hline Teaches most subjects in one group & & & $\mathrm{X}$ & $\mathrm{X}$ & & \\
\hline Teaches few subjects in several groups & $\mathrm{X}$ & $\mathrm{X}$ & & & $\mathrm{X}$ & $\mathrm{X}$ \\
\hline \multicolumn{7}{|l|}{ Educational setting } \\
\hline Alone with the students in separate classrooms & & $\mathrm{X}$ & $\mathrm{X}$ & & $\mathrm{X}$ & \\
\hline $\begin{array}{l}\text { Several teachers share responsibility for } \\
\text { large groups of students in open areas }\end{array}$ & $\mathrm{X}$ & & & & & $\mathrm{X}$ \\
\hline $\begin{array}{l}\text { Alone with one class of students in a large } \\
\text { open area with several classes }\end{array}$ & & & & $\mathrm{X}$ & & \\
\hline
\end{tabular}




\subsection{The Interviews}

Individual interviews were conducted in a semi-structured format. Semi-structured interviews were used because they allow the participants to express their thoughts and experiences in their own words. We started each interview by asking a general question about the respondents' thoughts about working as a teacher. This question was asked without any ques. We used follow-up questions such as: "Can you tell me more about that?" and "Can you elaborate on that?" Then, the interviewer asked open-ended questions about the teachers' educational goals and values, possible challenges in their work, and their reactions to the challenges and obstacles. The interviews lasted approximately 90 minutes and were conducted in an office or empty classroom chosen by the respondent. Before the interview, the teachers were informed that participation was voluntary, that they could withdraw from the interview at any time, and that they did not have to answer questions if they felt uncomfortable. The interviews were taped and transcribed.

\subsection{Data Analysis}

The interviews were audio-recorded and transcribed verbatim. In a first stage of the analysis, the transcripts were read several times by both authors to become familiar with the data. Thematic analyses were then conducted. We read the text over again searching for expressions concerning: 1) goals and values, 2) challenges and obstacles, 3) emotional and physical responses to the challenges and obstacles, and 4) strategies or attempts to cope with job demands or control the work situation. The statements in each of these themes were first categorized according to the wordings of the teachers. These categories were then narrowed down to fewer categories which encompassed similar meanings or thought processes (Creswell, 2005). The strategy statements were classified according to the respondents' statements about how they attempted or tried to control their work situation, irrespective of how well they felt that they succeeded. The coping categories were also analyzed to find if they fitted any of the control categories that were discussed in the introduction: personal, proxy, and collective control as well as primary (or positive) and secondary (or negative) control.

\section{Results}

\subsection{Educational Goals, Perceived Demands, and Emotional and Physical Responses}

In this section we provide a brief description of the educational goals, perceived demands, and emotional and physical responses to the demands for each participant. A summary of these descriptions is presented in Table 2.

\subsubsection{Hanna}

Hanna teaches social science and Norwegian at $6^{\text {th }}$ grade in an open area with 86 students and five teachers. The teacher team has a shared responsibility for all 
students although each teacher has the main responsibility for their "own" subjects. Hanna prefers to teach Norwegian and social science by means of lectures for the entire group of 86 students. Following these lectures, the students are working with assignments and all teachers in the team are helping and advising students during these sessions. When Hanna is talking about educational goals, she focuses solely on student academic achievement and dissemination of knowledge. She describes the goal structure of the school as achievement oriented and her colleagues as overly ambitious. She also expresses high personal ambitions related to student achievement.

Table 2. Job demands and physical and emotional responses described by the participants.

\begin{tabular}{|c|c|c|c|c|c|c|}
\hline & Hanna & Jane & Mary & Jon & Richard & Sam \\
\hline \multicolumn{7}{|l|}{ Primary educational goals } \\
\hline $\begin{array}{l}\text { Student academic achievement - } \\
\text { performance orientation }\end{array}$ & $\mathrm{X}$ & $\mathrm{X}$ & $\mathrm{X}$ & & & \\
\hline $\begin{array}{l}\text { Social, emotional, and professional } \\
\text { development - learning orientation }\end{array}$ & & & & $\mathrm{X}$ & $\mathrm{X}$ & $\mathrm{X}$ \\
\hline \multicolumn{7}{|l|}{ Job demands } \\
\hline Organizational demands & $\mathrm{x}$ & $\mathrm{X}$ & & $\mathrm{X}$ & $\mathrm{X}$ & $\mathrm{X}$ \\
\hline $\begin{array}{l}\text { Dysfunctional teamwork or } \\
\text { lack of collegial support }\end{array}$ & $\mathrm{X}$ & $\mathrm{X}$ & $\mathrm{X}$ & & $\mathrm{X}$ & $\mathrm{X}$ \\
\hline Disruptive student behavior & $\mathrm{X}$ & & $\mathrm{X}$ & & $\mathrm{X}$ & $\mathrm{X}$ \\
\hline $\begin{array}{l}\text { Difficult to develop positive } \\
\text { teacher-student relationships }\end{array}$ & & $\mathrm{X}$ & & & $\mathrm{X}$ & $\mathrm{X}$ \\
\hline Work overload /time pressure & $\mathrm{X}$ & $\mathrm{X}$ & $\mathrm{X}$ & & $\mathrm{X}$ & \\
\hline Student diversity & & & $\mathrm{X}$ & & $\mathrm{X}$ & $\mathrm{X}$ \\
\hline Documentation requirements & & & $\mathrm{X}$ & & $\mathrm{X}$ & \\
\hline Conflicts with the school principal & & & & $\mathrm{X}$ & & $\mathrm{X}$ \\
\hline Demanding parents & & $\mathrm{X}$ & & $\mathrm{x}$ & & \\
\hline $\begin{array}{l}\text { Lack of autonomy and } \\
\text { teacher codetermination }\end{array}$ & $\mathrm{X}$ & & & $\mathrm{X}$ & & $\mathrm{X}$ \\
\hline
\end{tabular}

Physical and emotional responses

\begin{tabular}{|c|c|c|c|c|c|c|}
\hline $\begin{array}{l}\text { Physical and emotional } \\
\text { exhaustion }\end{array}$ & $\mathrm{X}$ & $\mathrm{X}$ & $\mathrm{X}$ & $\mathrm{X}$ & $\mathrm{X}$ & $\mathrm{X}$ \\
\hline $\begin{array}{l}\text { sychosomatic symptoms } \\
\text { e.g., headache, back pain) }\end{array}$ & $\mathrm{X}$ & $\mathrm{X}$ & $\mathrm{X}$ & & & \\
\hline Sleeping problems & $\mathrm{X}$ & $\mathrm{X}$ & & & & \\
\hline Low job satisfaction & & & & & & $\mathrm{X}$ \\
\hline Fair of failure & & $\mathrm{X}$ & $\mathrm{X}$ & & $\mathrm{X}$ & \\
\hline tress explicitly mentioned & & $\mathrm{X}$ & $\mathrm{X}$ & & $\mathrm{X}$ & $\mathrm{X}$ \\
\hline
\end{tabular}


Hanna describes several demands related to this teaching strategy. Firstly, she says that the shared responsibility for a large group of students results in continuous conflicts with her colleagues. Secondly, in the open landscape, many students have problems concentrating during the lectures, resulting in what Hanna describes as disruptive student behavior. Additionally, she experiences a strong time pressure and work overload, that she partly attributes to her own ambitions and partly to the performance goal structure at school. She says:

It's stressful to feel that I $m$ not really done with the work, because I can always do more. Even if I have been working a whole week, on Sunday I still start wondering if I should have done a little more. The principal tells us that we must learn that good is good enough, but several of my colleagues do not agree. They believe that it should be extremely good to be good enough.

Hanna says that she loves working as a teacher. She particularly mentions working with the children and that every day brings new experiences. Nevertheless, she feels emotionally exhausted and attributes this development to long working days and disruptive student behavior. She also describes psychosomatic responses to her work situation and says:

I have had long periods where I have felt dead tired and I have a lot of headaches. I am falling asleep with a headache and it is there when I wake up.

\subsubsection{Jane}

Jane teaches English and French in $8^{\text {th }}$ grade in a classroom school. Because she teaches only English and French, she teaches many classes, but have each class only a few hours a week. Like Hanna, Jane emphasizes student academic achievement as her main educational goal. Like Hanna she has high ambitions regarding student achievement and is a hard-working teacher. Additionally, she works in a performance-oriented environment and describes the parents as demanding and expecting high grades. She says:

The last days I have worked eight hours at school and three to four hours at home at night. The principal has assigned me many tasks in addition to the teaching.

Jane is also concerned that a positive teacher-student relationship is important for optimal student learning and achievement. She underscores the importance of a good chemistry for student learning.

Like Hanna, Jane describes multiple demands in her job situation. She teaches a few school subjects in several classes and finds it tiring to relate to so many students. In addition, she finds it difficult to establish a good relationship with the students when she has each student for only a few hours a week. Jane also experiences an extremely high workload, which she partly attributes to many assignments in addition to her teaching responsibilities, partly to her own ambitions, and partly to demanding parents. She also describes teamwork as demanding. She says that there are twelve teachers at $8^{\text {th }}$ grade. These teachers form a teacher team, meeting one hour a week to plan the activities for the next week. She feels that the most experienced teachers provide too strong guidelines 
for the teaching. She expresses this as "being run over".

Like Hanna, Jane likes working with the students. But she also underscores that teaching is a demanding occupation. She characterizes her work as energy tapping and says that she feels mentally and physically exhausted. Jane says that she often experiences a fear of failure. She also experiences psychosomatic responses and has sleeping problems. She says:

My work is energy tapping and I often doubt that I will be able to continue working as a teacher. I also have a lot of tension in my body and my back is stiff. Last Autumn, after the summer vacation, I felt that I did not have the energy to start teaching again.

\subsubsection{Mary}

Mary is teaching most of the subjects in a fourth-grade class in a classroom school. She therefore gets to know each student well. Like Hanna and Jane, Mary's primary concern is on student academic achievement and dissemination of knowledge. She is also concerned about activating the students and fostering self-regulation. She says:

I really like to impart knowledge and organize teaching that activates the students. It is stimulating to see the students become more self-driven.

Already in the beginning of the interview, when asked a general question about her thoughts of working as a teacher, she mentioned five job demands: time pressure, documentation requirements, disruptive student behavior, student diversity, and dysfunctional team collaboration. The time pressure is partly due to the rigid documentation requirements. For instance, the teachers were required to document meetings with parents, conversations with students, the content of activity days, and details concerning developmental work. She says:

I feel that I am weighed down by the provision that everything we do must be documented in writing. It takes both time and effort and I often wonder who reads it and what benefit it has for the students.

Mary is concerned about adapting the education to individual students' needs. She therefore spends a lot of time preparing different assignments for different students. Nevertheless, she often feels that what she is able to do is not sufficient. She is particularly concerned about bright students who do not get enough of challenges in school. Mary also explains that teachers at the same grade level are expected to form teams. According to Mary, her team collaborate in developing a rough plan for the school year, but the team members are unwilling to disclose details regarding their teaching arrangements. Instead they compete about getting the best results.

Mary also says that she has always enjoyed working as a teacher. She particularly emphasizes working with the students and seeing that they learn and make progress. At the same time, she says that the total amount of work becomes too demanding and that she is physically and mentally tired. She says that by the end of the school day she sometimes "feel more dead than alive". She also says:

I am not good at dealing with many things at the same time. When I have too 
many tasks at the same time, I feel stress, get hot and hectic, and get a headache.

\subsubsection{Jon}

Jon teaches Norwegian, history, and social science in $9^{\text {th }}$ grade in an open area middle school. The $9^{\text {th }}$ grade students are organized in four classes and unlike Hanna's school, in Jon's school each teacher is responsible for their own group of students, even though they are all in the same room. However, all teachers at the same grade meet each week to plan the content and the activities for next week.

Jon is a student-centered teacher. He is concerned about intellectual as well as social and personal development of the students. He emphasizes the teacher-student relationship and individual student progress as important means for motivating the students. Therefore, he emphasizes the interaction with the students as the most important source to achieve his educational goals. He says:

The most important thing for me is the meeting with the students. It is the individual student who is in focus of my teaching. I also vary the teaching so that all students can develop their qualities.

Jon says that he has many ideas for his own teaching. But because all the teachers at each grade level are required to have the same content and activities in their teaching, Jon spends a lot of time arguing for his ideas. Sometimes, after spending much time preparing his teaching, he has to alter his plans because he does not get the team to agree on his ideas. He describes this as a serious job demand and says that he is dead tired of the way teaching is organized. Additionally, Jon describes the collaboration with the principal and the parents as strenuous and stressful.

Despite these demands, Jon describes his work as meaningful, flexible, exiting, and unpredictable, which he enjoys. He put in many hours in the evening preparing for his teaching and says that the planning gives him pleasure and adds to his job satisfaction. Nevertheless, sometimes he is physically exhausted after a school day. He says:

What we do is simply physically exhausting. You may be tired after a school day and feel like your head is swimming. But in recent years, the work has not drained me of energy. I think it is due to experience. I can often predict what will happen and can therefore prepare myself for how I will cope with the challenges.

\subsubsection{Richard}

Richard teaches Norwegian, mathematics, and social science in $9^{\text {th }}$ grade in several classes in a classroom middle school. He therefore teaches many students, but each group of students only a few hours a week. Like Jon, he is a student-centered teacher. He is concerned about motivating the students and focuses on individual improvement. He says:

There is so much potential in the students, and my task is to help them in their development, help each student to make progress, to experience mastery, and to be motivated for the schoolwork. 
I should have had more time with the students.

Richard tells about multiple demands in his job. Because he teaches few subjects in several classes, he feels that he meets each student too infrequently and to shortly each time. He therefore finds it difficult to develop a personal relationship with the individual students and describes the organizational model as a major barrier to achieving his educational goals. He says: "I should have had more time with the students". Like Mary, Richard tells about rigid documentation requirements that take a lot of time. Because he wants to prioritize the actual teaching and the preparations for it, he often postpones the documentation, which he refers to as paperwork. It therefore accumulates and contributes to a lot of stress. Another job demand that he describes as a major challenge, is one student with severe disruptive behavior. Richard also complains about the organization of the teachers in mandatory teams-one team for each school subject and one team for each grade level. This results in many meetings that he feels adds to the time pressure. He describes the meeting as dysfunctional because they give little opportunity to address problems that he would like to address.

Richard says that he experiences a lot of stress at work. He experiences that the requirement for documentation and the student with behavioral problems constitute a barrier to goal achievement. He further says that the stress reappears in the evening when he thinks of all the documentation that has accumulated. This makes him physically and emotionally exhausted. He says:

The job stresses me from eight in the morning to four in the afternoon. I do my best to discriminate between work and leisure, but in the evening the job is still in my mind. Then I start thinking about everything that should have been done and feel physical and emotional exhausted.

\subsubsection{Sam}

Sam is teaching a sixth-grade class in an open area elementary school. Four teachers have a common responsibility for teaching a large group of 72 students. Sam emphasizes the importance of a collegium where they can share experiences and develop common educational goals and values. Sam is a student-centered teacher emphasizing the importance of a mastery-oriented learning environment stimulating the progress of the individual students. He says:

I thrive when students thrive and when they develop academically. I place great emphasis on my relations with the students and on developing a positive social environment.

Sam describes six different but overlapping demands in his job situation. $\mathrm{He}$ characterizes the organizational model with four teachers being responsible for a larger group of students as a straitjacket where he has little autonomy and is deprived of the control over his own teaching. Being forced to work together with a large group of students has in his conceptualization resulted in much conflict because the teachers have different ideas about what constitutes good education. He also notes that the organizational model, where he must relate to a large 
group of students, makes it difficult to develop close relations with the students. Sam also describes the behavior of some students as disruptive and attributes the behavior problems to the organizational model with too many students in the same area. Additionally, Sam perceives the principal as authoritarian and calls for co-determination for the teachers. It is, for example, the principal who has decided the organizational model and who does not allow a discussion about it.

Sam experiences the job demands as obstacles in achieving his educational goals, which results in stress, exhaustion, and lower job satisfaction. He says:

I feel stress at work when it is noisy, and the students are walking around in the landscape. I get angry and feel that I have not done a good job. I was completely exhausted at Christmas time, due to a combination of conflicts in the teacher team and that I did not see the point of what we were doing.

\subsection{Coping Strategies}

In this section we provide a brief description of the coping strategies used by the participating teachers. A summary of these strategies is presented in Table 3.

\subsubsection{Hanna}

Hanna is ambitious and achievement oriented, but also describes the school structure as performance oriented. Her primary strategy is hard work and increased effort. As already noted, she said that even if she had been working a whole week, on Sunday she still started wondering if she should have done a little more. Also, as noted above, she described emotional exhaustion and psychosomatic symptoms as the result of the hard work. From time to time, when she was unable to continue the same pace of work, she used sick leave (asking her doctor for sick leave) as a secondary strategy. She also was treated by a physiotherapist twice a week. At the time of the interview she had recently reduced her teaching position by 20 percent. She said:

I do not have many sick days, but I have had to take the occasional day off when it was at its worst. I also go to physical therapy to be able to stay at work.

\subsubsection{Jane}

Jane is also ambitious and achievement oriented. Like Hanna, her main strategy is hard work. The intense work erodes her health, and to gather strength she chooses to apply for sick leave for shorter periods. She says:

It happens that I am absent from school because I am tired, but it is not often. I must take-care of myself, otherwise I will not last long.

\subsubsection{Mary}

Mary, describes her work as intense, partly due to the documentation requirements. She also describes herself as physically and mentally exhausted. Her primary strategy is to lie down on the couch and rest when she comes home from work. The job demands and health problems have led to her being 20 percent on sick leave at the time of the interview. She says she plans to apply for 20 percent disability benefits. 
Table 3. Coping strategies.

\begin{tabular}{|c|c|c|c|c|c|c|}
\hline Strategies & Hanna & Jane & Mary & Jon & Richard & Sam \\
\hline $\begin{array}{l}\text { Increased effort - } \\
\text { hard work }\end{array}$ & $\mathrm{X}$ & $\mathrm{X}$ & & & & \\
\hline Sick leave & $\mathrm{X}$ & $\mathrm{X}$ & $\mathrm{X}$ & & & \\
\hline Physiotherapy & $\mathrm{X}$ & & & & & \\
\hline $\begin{array}{l}\text { Reduce the } \\
\text { teaching position }\end{array}$ & $\mathrm{X}$ & & $\mathrm{X}$ & & & \\
\hline $\begin{array}{l}\text { Rest after working hours } \\
\quad \text { (e.g., on the couch) }\end{array}$ & & & $\mathrm{X}$ & & & \\
\hline Argue for one's ideas & & & & $\mathrm{X}$ & & \\
\hline Exercise & & & & $\mathrm{X}$ & & \\
\hline $\begin{array}{c}\text { Procrastination } \\
\text { (e.g., postpone paperwork) }\end{array}$ & & & & & $\mathrm{X}$ & \\
\hline Help seeking & & & & & $\mathrm{X}$ & $\mathrm{X}$ \\
\hline $\begin{array}{l}\text { Keep accounts } \\
\text { of one's duties }\end{array}$ & & & & & & $\mathrm{X}$ \\
\hline
\end{tabular}

\subsubsection{Jon}

Jon, describes his work as physically exhausting. When he feels exhausted, his primary strategy is exercising (jogging). He also says that his primary job demand is that all the teachers at each grade level are required to have the same content and activities in their teaching. However, there is little agreement about educational goals and means in his team. He therefore spends much time arguing for his ideas, which in his perception sometimes works and sometime not. Regarding his actual teaching, he seems to attribute the results to controllable causes and look for alternative means when he does not succeed. He says:

When I have gotten into a situation I do not master, I solve it by changing direction. I cannot remember that I have been in a situation where I have not found a way out.

\subsubsection{Richard}

Richard has no adequate strategy to reduce the workload. He responds to the documentation requirement by postponing what he terms "paperwork". This strategy results in an accumulation of paperwork that still needs to be done. Richard also has no strategy to change the lack of student motivation he experiences. He says:

It is often the case at school that you give and give, and then you do not get anything back. That feeling is not good, but it is only to realize that this is how it is.

Richard also had one student with severe behavior problems. For this job demand his strategy was to seek professional help at the municipal special education service. However, he did not receive any help before the end of the academic year. 


\subsubsection{Sam}

Sam's strategy to avoid extra assignments, that he is given by the school principal, is to keep account of the time he spends on various tasks. When asked to take on extra tasks, he presents the account and asks the principal to decide which of the current tasks he should drop. He also shows help seeking behavior regarding students with learning difficulties by asking the internal special education service at school for help. Regarding students with disruptive behavior he has no strategy.

\section{Discussion}

\subsection{Job Demands}

Supporting previous research (e.g., Liu \& Onwuegbuzie, 2012; Skaalvik \& Skaalvik 2017a, 2017b; Stoeber \& Rennert, 2008), all six teachers emphasized that the work as a teacher made them physically and emotionally exhausted, and four of the teachers explicitly characterized the work as stressful. Three of the teachers also told that they experienced psychosomatic symptoms.

\subsubsection{Three Categories of Job Demands}

The interviews revealed that the teachers perceived multiple job demands. The teachers mentioned ten partly overlapping obstacles or job demands and each teacher mentioned between four and seven demands (see Table 2). Nine of the demands may be seen as constituting three major categories of challenges and obstacles: time pressure, demanding social interactions, and lack of autonomy. 1) The time pressure or work overload has in previous quantitative research been identified as a major demand that is strongly associated with emotional exhaustion (Skaalvik \& Skaalvik, 2017c). The time pressure has been attributed to an increasing number of work assignments in the teaching profession (Buchanan, 2010; Hargreaves, 2003). Additionally, the present study indicates that the time pressure may be increased by rigid requirements for documentation, student diversity, and demanding parents, as well as high ambitions regarding student achievement. 2) The teachers also mentioned several demanding social interactions: dysfunctional teamwork, conflicts with the school leadership, and disruptive student behavior. Disruptive student behavior has in previous research been identified as a major job demand in the teacher profession (Klassen \& Chiu, 2011; Klassen et al., 2013; Skaalvik \& Skaalvik, 2011), and as a demand that is associated with emotional exhaustion and cynicism (Skaalvik \& Skaalvik, 2010). Additionally, three of the teachers emphasized difficulties establishing close personal relationships with the students as a major problem. 3) In our analysis, the third category consists of lack of individual autonomy as well as a lack of codetermination for the teaching staff. Autonomy is in self-determination theory also regarded as one of the basic psychological needs.

\subsubsection{Physical and Organizational Models Contributing to the Demands}

Five of the six teachers emphasized physical and organizational models as con- 
tributing to the job demands. Several of the challenges and obstacles, that we classified as demanding social interactions and lack of autonomy, may be traced back to physical and organizational models or solutions:

1) A common feature mentioned by all participating teachers, was the requirement that all the teachers at the same grade level should form a teacher team. Teamwork or collaboration was mandatory and scheduled, but without clear guidelines for the work. Four of the teachers also emphasized that, in each school subject, they were required to follow a common plan for their teaching. The interviews indicate that the mandatory teamwork may result in different demands: conflicts between the team members, meetings that are perceived as a waste of time because they are poorly prepared, and lack of autonomy due to dominating teachers and the requirement to follow a common plan for the teaching. A possible interpretation is that the developing of a collective culture with common goals and values is a requirement for mandatory teacher cooperation to be fruitful. None of the participating teachers reported such a culture at their school.

2) Three of the teachers, who were teaching in open area schools, attributed both disruptive student behavior and concentration problems among the students to large groups of students being taught in an open area. They said that the teachers lost track of the students, and some of the students walked around in the open landscape. Other students had difficulty concentrating on schoolwork due to the lack of peace and order.

3) Two of the three teachers who taught in open areas described an organizational model where 4 - 5 teachers had a common responsibility for 70 - 80 students. According to these teachers, this organizational model resulted in several job demands. One of the teachers, who was concerned about a positive teacher-student relation, said that having co-responsibility for so many students made it difficult to develop close relations with the students. Both teachers said that the organizational model increased the conflicts between the teachers, who had quite different ideas about education. Also, they both felt that this way of organizing the education increased the lack of individual autonomy that is already described as a result of the mandatory teamwork. We suggest that, like the requirement for teacher cooperation during preparation for teaching, shared responsibility for the actual teaching requires the development of a collective culture characterized by common goals and values.

4) Four of the teachers were teaching only two or three school subjects. They were teaching these subjects in several classes. They were therefore teaching a large number of students, but had each student only a few hours a week. Two problems seem to be associated with this organizational model, that is common in Norwegian middle school. Firstly, the model prevents the teachers from getting to know the students well, developing a close relationship with them, and providing the social (emotional and instrumental) support that the students need. Secondly, one teacher emphasized that it was tiring to relate to so many students. 
Despite all the demands, the teachers expressed high job satisfaction, which they attributed to working with the students. This is in accordance with previous research (Skaalvik \& Skaalvik, 2011, 2012) that also shows that job satisfaction is positively associated with motivation to continue teaching. Nevertheless, both the results of this study and of previous research reveal an urgent need to reduce the total demands on the teachers. For instance, previous research show that job demands are, directly and indirectly, associated with motivation for leaving the teaching profession (Skaalvik \& Skaalvik, 2017a, 2018) and with actual teacher attrition (for a review, see Räsänen, Pietarinen, Pyhältö, Soini, \& Väisänen, 2020).

\subsection{Control Strategies}

The analyses showed that the participating teachers used five main strategies to control or master their work situation. We term these strategies: hard working strategies, recovering strategies, reducing the workload strategies, job crafting strategies, and help seeking strategies.

\subsubsection{Hard-Working Strategies}

Two of the teachers used hard-working strategies to meet their own ambitions as well as the expectations that they felt were directed towards them. These strategies represent personal control. The teachers described work environments that were demanding and exhausting due to work overload. The hard-working strategies do not change these realities. Rather, they represent attempts to make the best out of the situation without changing it, which characterizes secondary control. The hard-working strategies also resulted in additional problems which characterizes negative control, for example emotional exhaustion and psychosomatic responses.

\subsubsection{Recovering Strategies}

Four of the teachers reported using what we term recovering strategies-strategies aimed at regaining their strength and energy. In periods when they felt exhausted, three of the teachers asked their medical doctor for sick leave. Other examples of recovering strategies were seeking physiotherapy, resting on the couch after work, and exercising. Thus, the teachers used multiple recovering strategies. These strategies represent different forms of personal control although they involve services from medical doctors and physiotherapists. They are also not changing the situation that leads to exhaustion and psychosomatic responses. Thus, they may best be classified as secondary control.

\subsubsection{Reducing the Workload Strategies}

Three of the teachers also used strategies aimed at reducing or controlling the actual workload. The strategies aimed at reducing the workload were reducing the teaching position by 20 percent to get one extra day off, and to keep account of the work tasks and use the account as a bargaining chip to avoid additional tasks. Reducing the teaching position by 20 percent actually changes the re- 
quired workload and therefore resembles a primary control. However, the strategy is costly in terms of reduced income. We therefore tend to classify this strategy as a negative control. On the other hand, keeping account of what one is doing may change a situation where one is often given additional assignments that lead to work overload. It therefore represents an attempt to use primary control. However, the bargaining strategy did not put the teacher in control of his work situation.

\subsubsection{Job Crafting Strategies}

Two of the teachers used strategies that may be classified as job crafting strategies - strategies aimed at controlling the content of the job or how the job is performed. One teacher said that he had many ideas for his teaching, and because all teachers at the grade level were required to follow a common teaching plan, he used the meetings arguing for his plan. This is the way he sought to craft the work as close to his own ideas as possible. This strategy may be perceived both as personal and collective control, and as an attempt at primary control. Another teacher, who was required to do a lot of documentation, used procrastination as a strategy. He pushed away the paperwork to concentrate on the teaching and the preparation for teaching. However, this strategy only worked for a limited time. The paperwork piled up and became even more demanding when it finally had to be done. The strategy therefore did not change the situation in the long run and is therefore best classified as a secondary, but negative control.

\subsubsection{Help Seeking Strategies}

Two of the teachers addressed both disruptive student behavior and learning disabilities by seeking help from the school's special educator or the special education service in the municipality. These strategies represent attempts of both proxy control and a possible primary control. Unfortunately, none of these teachers received the help they sought before the end of the school year.

\subsection{General Discussion}

This study indicates that teachers experience multiple demands at work and that, for many teachers the sum of the demands results in stress and emotional exhaustion, or more generally, in a health impairment process (Demerouti et al., 2001). In social cognitive theory being an agent is defined as influencing intentionally one's functioning and life circumstances (Bandura, 2006). Unfortunately, this study indicates that the teachers see few opportunities to control or alter important aspects of their work situation. The analysis of the interviews reveals few attempts at proxy or collective control. Rather, the teachers described attempts to cope with the demands on their own (personal control). The interviews also indicated that the teachers made little us of primary control, which would be characterized by attempts to change the demanding situation or reduce the job demands. Instead, they used a variety of secondary control strategies aimed at being able to live with the demanding circumstances at work. The few 
attempts at primary control that the teachers told about were partly inadequate (e.g., procrastination), partly costly for the teachers (e.g., reducing the teaching position), and partly did not work well because they were based on help and support that they never received (e.g., the special education service).

The lack of primary control that was described by the teachers may partly be interpreted as a result of structural and organizational conditions over which teachers 1) had no influence or 2) believed that they had no influence (see section 5.1.). In both cases, primary control may appear impossible. What appears possible is to find ways to live with the unchangeable situation, which leads to secondary control. The infrequent use of proxy and collective control may also be understood as a result of structural and organizational conditions that were perceived as unchangeable. If the structural conditions cannot be changed, seeking help and collaboration may not appear as a possible solution. Another possible interpretation is that the particular schools were the teachers were working had not developed a collective culture characterized by common goals and values and a supportive collegial environment. This interpretation is supported by several statements referring to competition among the teachers as well as a lack of agreement about educational goals and means.

As noted above, there is an urgent need finding measures to reduce the level of stress in the teaching profession. Moreover, teachers need decision latitude to craft their own working situation, make it meaningful, and reduce stress. Based on the present study we propose several measures. To the extent that it is possible, the educational goals, values, and means should be clarified before choosing organizational models. For example, research shows that a close and positive teacher-student relationship is highly valued by the students and that it is associated with student motivation (Bakx, Houtert, van de Brand, \& Hornstra, 2019; Federici \& Skaalvik, 2014a, 2014b). In order to develop such a teacher-student relationship it is important to choose organizational models that facilitate such a development. These models must be chosen to fit the goals and values whereas the present study exemplifies organizational models that do not fit the teachers' goals. As illustrated in this study, teachers may have different goals and values for their teaching, making it difficult to fit organizational models to their goals and values. An important task for the school leadership should therefore be to work to develop a collective culture characterized by common goals and values as well as general principles for teaching practices. Such an endeavor must be built on ongoing discussions in the teacher collegium. However, it is also crucial to maintain some degree of teacher autonomy. Within the framework of common goals and values, it is therefore important to clarify the boundaries of teacher autonomy which we perceive as a basic psychological need with strong impact on engagement (see Deci \& Ryan, 2000). Another implication of this study is that the school leadership should reduce unnecessary meetings and documentation that takes time that might rather be used for professional learning and preparation for teaching. Also, our analyses indicate that collaboration in teacher teams requires clear guidelines for the collaboration as well as a common 
perception of educational goals and values. In our conceptualization, developing such guidelines and common perceptions of goals and values are core tasks for the school leadership.

The present study has several limitations that call for future research. We only interviewed six teachers. Therefore, although we found multiple demands and coping strategies, more research is needed to explore other demands and strategies, which demands and strategies are most frequently mentioned by the teachers, and which strategies actually are suited for reducing the health impairment process related to job demands. Both quantitative and longitudinal researches are called for. We also should point out that the teachers in this study were still working as teachers. However, international research also reveals that teacher attrition-the departure of teachers from their teaching jobs-has become a global problem (e.g., Chang, 2009; Hong, 2012; Ingersoll, 2001). Leaving the teaching profession is therefore a strategy that could not be investigated in this study.

Although the number of participants in this study was small, we may conclude that teachers both perceive multiple demands and use multiple coping strategies. However, we should note that the number of participants does not allow analyses of systematic relations between perceived demands and such variables age, gender, and grade level. Such analyses call for survey designs with large and representative samples.

\section{Conflicts of Interest}

The authors have no conflict of interest or competing interests to declare.

The study was conducted in line with the ethical research guidelines and approved by the Norwegian Centre for Research Data (NSD) which serves as a national ethical research committee.

\section{References}

Bakker, A. B., \& Demerouti, E. (2006). The Job Demands-Resources Model: State of the Art. Journal of Managerial Psychology, 22, 309-328. https://doi.org/10.1108/02683940710733115

Bakx, A., Houtert, T. V., van de Brand, M., \& Hornstra, L. (2019). A Comparison of High Ability Pupils' Views vs. Regular Ability Pupils' Views of Characteristics of Good Primary School Teachers. Educational Studies, 45, 35-56. https://doi.org/10.1080/03055698.2017.1390443

Bandura, A. (1997). Self-Efficacy: The Exercise of Control. New York, NY: Freeman.

Bandura, A. (2000). Exercise of Human Agency through Collective Efficacy. Current Directions in Psychological Science, 9, 75-78. https://doi.org/10.1111/1467-8721.00064

Bandura, A. (2006). Adolescent Development from an Agentic Perspective. In F. Pajares, \& T. Urdan (Eds.), Self-Efficacy Beliefs of Adolescents (pp. 1-43). Greenwich, CT: Information Age Publishing.

Betoret, F. D. (2009). Self-Efficacy, School Resources, Job Stressors and Burnout among Spanish Primary and Secondary School Teachers: A Structural Equation Approach. Educational Psychology, 29, 45-68. https://doi.org/10.1080/01443410802459234

Borman, G. D., \& Dowling, N. M. (2008). Teacher Attrition and Retention: A Me- 
ta-Analytic and Narrative Review of the Research. Review of Educational Research, 78, 367-409. https://doi.org/10.3102/0034654308321455

Buchanan, J. (2010). May I Be Excused? Why Teachers Leave the Profession. Asia Pacific Journal of Education, 30, 199-211. https://doi.org/10.1080/02188791003721952

Chan, D. (2002). Stress, Self-Efficacy, Social Support, and Psychological Distress among Prospective Teachers in Hong Kong. Educational Psychology, 22, 557-570. https://doi.org/10.1080/0144341022000023635

Chang, M. L. (2009). An Appraisal Perspective of Teacher Burnout: Examining the Emotional Work of Teachers. Educational Psychology Review, 21, 193-218.

https://doi.org/10.1007/s10648-009-9106-y

Covington, M. V. (1992). Making the Grade: A Self-Worth Perspective on Motivation and School Reform. Cambridge: Cambridge University Press. https://doi.org/10.1017/CBO9781139173582

Creswell, J. W. (2005). Educational Research: Planning, Conducting, and Evaluating Quantitative and Qualitative Research. New Jersey: Pearson.

Deci, E. L. \& Ryan, R. M. (2000). The "What" and "Why" of Goal Pursuits: Human Needs and the Self-Determination of Behavior. Psychological Inquiry, 11, 227-268. https://doi.org/10.1207/S15327965PLI1104 01

Demerouti, E., Bakker, A. B., Nachreiner, F., \& Schaufeli, W. B. (2001). The Job Demands-Resources Model of Burnout. Journal of Applied Psychology, 86, 499-512. https://doi.org/10.1037/0021-9010.86.3.499

Federici, R. A., \& Skaalvik, E. M. (2014a). Students' Perceptions of Emotional and Instrumental Teacher Support: Relations with Motivational and Emotional Responses. International Education Studies, 7, 21-36. https://doi.org/10.5539/ies.v7n1p21

Federici, R. A., \& Skaalvik, E. M. (2014b). Students' Perception of Instrumental Support and Effort in Mathematics: The Mediating Role of Subjective Task Values. Social Psychology of Education, 17, 527-540. https://doi.org/10.1007/s11218-014-9264-8

Fernet, C., Guay, F., Senécal, C., \& Austin, S. (2012). Predicting Intra-Individual Changes in Teacher Burnout: The Role of Perceived School Environment and Motivational Factors. Teaching and Teacher Education, 28, 514-525.

https://doi.org/10.1016/j.tate.2011.11.013

Friedman, I. A. (1995). Student Behavior Patterns Contributing to Teacher Burnout. Journal of Educational Research, 88, 281-333. https://doi.org/10.1080/00220671.1995.9941312

Hakanen, J. J., Bakker, A. B., \& Schaufeli, W. B. (2006). Burnout and Work Engagement among Teachers. Journal of School Psychology, 43, 495-513. https://doi.org/10.1016/j.jsp.2005.11.001

Hargreaves, A. (2003). Teaching in the Knowledge Society: Education in the Age of Insecurity. MiltonKeynes: Open University Press.

Harter, S. (1982). The Perceived Competence Scale for Children. Child Development, 53, 87-97. https://doi.org/10.2307/1129640

Hong, J. Y. (2012). Why Do Some Beginning Teachers Leave the School, and Others Stay? Understanding Teacher Resilience through Psychological Lenses. Teaching and Teacher Education, 18, 417-440. https://doi.org/10.1080/13540602.2012.696044

Ingersoll, R. M. (2001). Teacher turnover and teacher shortages: An organizational analysis. American Educational Research Journal, 38, 499-534.

https://doi.org/10.3102/00028312038003499

Johnson, S., Cooper, C., Cartwright, S., Donald, I., Taylor, P., \& Millet, C. (2005). The 
Experience of Work-Related Stress across Occupations. Journal of Managerial Psychology, 20, 178-187. https://doi.org/10.1108/02683940510579803

Klassen, R., \& Chiu, M. M. (2011). The Occupational Commitment and Intention to Quit of Practicing and Pre-Service Teachers: Influence of Self-Efficacy, Job Stress, and Teaching Context. Contemporary Educational Psychology, 36, 114-129. https://doi.org/10.1016/j.cedpsych.2011.01.002

Klassen, R., Wilson, E., Siu, A. F. Y., Hannok, W., Wong, M. W., Wongsri, N. et al. (2013). Preservice Teachers' Work Stress, Self-Efficacy, and Occupational Commitment in Four Countries. European Journal of Psychology of Education, 28, 1289-1309. https://doi.org/10.1007/s10212-012-0166-x

Kokkinos, C. M. (2007). Job Stressors, Personality and Burnout in Primary School Teachers. British Journal of Educational Psychology, 77, 229-243. https://doi.org/10.1348/000709905X90344

Liu, S., \& Onwuegbuzie, A. J. (2012). Chinese Teachers' Work Stress and Their Turnover Intention. International Journal of Educational Research, 53, 160-170. https://doi.org/10.1016/j.ijer.2012.03.006

Montgomery, C., \& Rupp, A. A. (2005). Meta-Analysis for Exploring the Diversity Causes and Effects of Stress in Teachers. Canadian Journal of Education, 28, 458-486. https://doi.org/10.2307/4126479

Räsänen, K., Pietarinen, J., Pyhältö, K., Soini, T., \& Väisänen, P. (2020). Why Leave the Teaching Profession? A Longitudinal Approach to the Prevalence and Persistence of Teacher Turnover Intentions. Social Psychology of Education, 23, 837-859. https://doi.org/10.1007/s11218-020-09567-X

Rothbaum, F., Weisz, J. R., \& Snyder, S. S. (1982). Changing the World and Changing the Self: A Two-Process Model of Perceived Control. Journal of Personality and Social Psychology, 42, 5-37. https://doi.org/10.1037/0022-3514.42.1.5

Schunk, D. H., Pintrich, P. R. \& Meece, J. L. (2010). Motivation in Education: Theory, Research, and Applications (3th ed.). New York, NY: Pearson.

Skaalvik, C. (2020). Emotional Exhaustion and Job Satisfaction among Norwegian School Principals: Relations with Perceived Job Demands and Job Resources. International Journal of Leadership in Education. https://doi.org/10.1080/13603124.2020.1791964

Skaalvik, E. M., \& Skaalvik, S. (2009). Does School Context Matter? Relations with Teacher Burnout and Job Satisfaction. Teaching and Teacher Education, 25, 518-524. https://doi.org/10.1016/j.tate.2008.12.006

Skaalvik, E. M., \& Skaalvik, S. (2010). Teacher Self-Efficacy and Teacher Burnout: A Study of Relations. Teaching and Teacher Education, 26, 1059-1069. https://doi.org/10.1016/j.tate.2009.11.001

Skaalvik, E. M., \& Skaalvik, S. (2011). Teacher Job Satisfaction and Motivation to Leave the Teaching Profession: Relations with School Context, Feeling of Belonging, and Emotional Exhaustion. Teaching and Teacher Education, 27, 1029-1038. https://doi.org/10.1016/j.tate.2011.04.001

Skaalvik, E. M., \& Skaalvik, S. (2012). Skolen som Arbeidsplass. Trivsel, mestring og utfordringer. [School as a Workplace for Teachers]. Oslo: Universitetsforlaget.

Skaalvik, E. M., \& Skaalvik, S. (2015). Job Satisfaction, Stress, and Coping Strategies in the Teaching Profession. What Do the Teachers Say? International Education Studies, 8, 181-192. https://doi.org/10.5539/ies.v8n3p181

Skaalvik, E. M. \& Skaalvik, S. (2017a). Still Motivated to Teach? A Study of School Context Variables, Stress and Job Satisfaction among Teachers in Senior High School. So- 
cial Psychology of Education, 20, 15-37. https://doi.org/10.1007/s11218-016-9363-9

Skaalvik, E. M. \& Skaalvik, S. (2017b). Teacher Stress and Teacher Self-Efficacy: Relations and Consequences. In T. M. McIntyre, S. E. McIntyre, \& D. J. Francis (Eds.), Educator Stress: An Occupational Health Perspective (pp. 101-125). Cham: Springer. https://doi.org/10.1007/978-3-319-53053-6 5

Skaalvik, E. M., \& Skaalvik, S. (2017c). Dimensions of Teacher Burnout: Relations with Potential Stressors at School. Social Psychology of Education, 20, 775-790. https://doi.org/10.1007/s11218-017-9391-0

Skaalvik, E. M., \& Skaalvik, S. (2018). Job Demands and Job Resources as Predictors of Teacher Motivation and Well-Being. Social Psychology of Education, 21, 1251-1275. https://doi.org/10.1007/s11218-018-9464-8

Skaalvik, S. (1995). Voksne med lese-og skrivevansker forteller om sine skoleerfaringer (Adults with Reading Problems Tell about Their Experiences in School). Doctorial Dissertation, Trondheim: Norwegian University of Science and Technology.

Stoeber, J., \& Rennert, D. (2008). Perfectionism in School Teachers: Relations with Stress Appraisals, Coping Styles, and Burnout. Anxiety, Stress, \& Coping, 21, 37-53. https://doi.org/10.1080/10615800701742461

White, R. W. (1959). Motivation Reconsidered: The Concept of Competence. Psychological Review, 66, 297-333. https://doi.org/10.1037/h0040934 